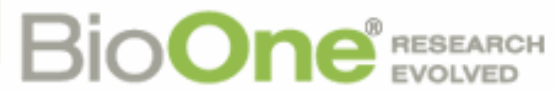

\section{River-Based Surveys for Assessing Riparian Bird Populations: Cerulean Warbler as a Test Case}

Author(s): Mark B. Robbins, Árpád S. Nyári, Monica Papeş, Brett W. Benz and Brian R. Barber

Source: Southeastern Naturalist, 9(1):95-104.

Published By: Eagle Hill Institute

DOI: http://dx.doi.org/10.1656/058.009.0108

URL: http://www.bioone.org/doi/full/10.1656/058.009.0108

BioOne (www.bioone.org) is a nonprofit, online aggregation of core research in the biological, ecological, and environmental sciences. BioOne provides a sustainable online platform for over 170 journals and books published by nonprofit societies, associations, museums, institutions, and presses.

Your use of this PDF, the BioOne Web site, and all posted and associated content indicates your acceptance of BioOne's Terms of Use, available at www.bioone.org/page/terms of use.

Usage of BioOne content is strictly limited to personal, educational, and noncommercial use. Commercial inquiries or rights and permissions requests should be directed to the individual publisher as copyright holder. 


\title{
River-based Surveys for Assessing Riparian Bird Populations: Cerulean Warbler as a Test Case
}

\author{
Mark B. Robbins ${ }^{1, *}$, Árpád S. Nyári ${ }^{1}$, Monica Papeş ${ }^{1}$, Brett W. Benz ${ }^{1}$, \\ and Brian R. Barber ${ }^{1,2}$
}

\begin{abstract}
Birds concentrated in riparian habitats are poorly sampled by traditional survey methods because of the difficulties associated with accessing these habitats. Our objectives were to test the effectiveness of river-based surveys to determine the status, distribution, and relative abundance for riparian bird species in Missouri and northern Arkansas, with special emphasis on Dendroica cerulea (Cerulean Warbler). Our canoe-based surveys revealed an average of 2.3 and 0.8 singing male Cerulean Warblers/river km along the Current River (128 river km surveyed), MO, and the Buffalo National River (96 river km), AR. Nonparametric estimates for repeated surveys of the same river stretches indicate that $69-79 \%$ of singing male Cerulean Warblers were detected. However, the bias associated with the estimate methodology and independent song rate data suggest those are conservative estimates. In comparison with land-based point-counts, this river-based protocol offers a quick and efficient assessment of Cerulean Warblers in riparian areas.
\end{abstract}

\section{Introduction}

Riparian birds are among the most under-sampled category of birds in North America due to the difficulty in accessing the habitat (Fletcher and Hutto 2006, Peterjohn 1994). The most comprehensive data set for assessing North American avian population trends, the United States Geological Survey (USGS) Breeding Bird Survey (BBS), is limited to road-based surveys and therefore samples only a small proportion of riparian habitats. Studies using BBS data to assess population estimates, trends, conservation priorities, or depict distributions with relative abundance isoclines (James et al. 1992, Panjabi et al. 2005, Price et al. 1995, Rich et al. 2004, Rosenberg and Blancher 2005) of riparian species have suffered from limited sample sizes as well as other biases (Confer et al. 2008, Link and Sauer 2002, Thogmartin et al. 2006). One approach to solving this problem has been to lump data from multiple habitats into single estimates (e.g., Sauer and Droege 1992), but trends for better-sampled habitats mask trends for less-sampled riparian habitats (Robbins et al. 1986).

Link and Sauer (2002) underscored that species like Dendroica cerulea Wilson (Cerulean Warbler) are poorly sampled using BBS protocol since relatively few individuals are encountered because the roadside surveys transverse only a limited portion of the species' habitats. Across much of

\footnotetext{
${ }^{1}$ The University of Kansas Natural History Museum and Biodiversity Research Center, 1345 Jayhawk Boulevard, Lawrence, KS 66045. '2Department of Biology, Brigham Young University, Central 401 WIDB, Provo, UT 84602. " Corresponding author-mrobbins@ku.edu.
} 
its distribution, the Cerulean Warbler breeds in riparian habitat, and in some regions, such as Missouri and Arkansas, a large proportion of its populations are in riparian forest, which have been poorly sampled using conventional survey methods (Jacobs and Wilson 1997, Robbins et al. 1998; data presented herein). To address this issue, we conducted river-based surveys for 15-19 species, depending on species composition, across 16 river systems $(760 \mathrm{~km})$ in Missouri and northern Arkansas. As a test case for using this method to assess riparian bird populations, we present results for Cerulean Warblers, a species that has been reported as having suffered the most significant decline of any passerine in North America during the 40-year history of the BBS (Hamel 2000a, b; Hamel et al. 2004; Robbins et al. 1992).

\section{Methods and Study Areas}

From 1992 through 2006 we conducted surveys of 15-19 species of riparian-inhabiting avian species across 16 rivers systems (760 river $\mathrm{km}$ ) in Missouri and northern Arkansas (Robbins 2003; M.B. Robbins, unpubl. Data; Robbins et al. 1998). Here we present results from surveys conducted in 2003 and 2004 on the Current River and 2006 on the Buffalo River. In an attempt to estimate the number of individuals detected by this protocol, we conducted repeat surveys of three sections of two of these rivers. Locations and dates of repeat surveys were: upper Current River Pulltite access $\left(37^{\circ} 20.0^{\prime} \mathrm{N}, 91^{\circ} 28.5^{\prime} \mathrm{W}\right)$ to Round Spring access $\left(37^{\circ} 16.8^{\prime} \mathrm{N}, 91^{\circ} 24.2^{\prime} \mathrm{W}\right)$ (15.4 river $\mathrm{km}$ ), 25-26 May 2004 and Round Spring access to Jerktail Landing $\left(37^{\circ} 13.7^{\prime} \mathrm{N}, 91^{\circ} 18.5^{\prime} \mathrm{W}\right)$ (19.8 river $\left.\mathrm{km}\right), 27-28$ May 2004; Buffalo National River: Maumee North access $\left(36^{\circ} 02.11^{\prime} \mathrm{N}, 92^{\circ} 37.70^{\prime} \mathrm{W}\right)$ to Highway 14 access $\left(36^{\circ} 04.03^{\prime} \mathrm{N}, 92^{\circ} 34.73^{\prime} \mathrm{W}\right)(15.7$ river $\mathrm{km}), 2$ and 4 June 2006. Each repeated river section was subdivided into three subsections so withinsection variability could be analyzed.

All surveys were initiated at 05:00 hrs (CST), from a canoe with little to no paddling and at average flow rates $( \pm \mathrm{SD})$ of $4.0 \pm 0.5 \mathrm{~km} / \mathrm{hr}(4.1 \pm 0.4$ for repeat surveys only). No surveys were done under river flow extremes, i.e., after heavy rains which increased flow and noise, or during low water levels, and only under conditions of no precipitation and no or very light wind. A global positioning system unit (Garmin 12, Map Datum WGS 84) was continually used to monitor canoe flow rate during all surveys. In areas of relatively fast flow, e.g., short, narrow stretches with associated riffles at a sharp bend in the river, we either stopped prior to or immediately after such areas for 3-5 min to increase the likelihood that singing males would be detected. We surveyed river sections that did not exceed $20 \mathrm{~km}$ (with one exception) in length each day to ensure that surveys were completed by ca. 10:00 hrs. River width was generally $<50 \mathrm{~m}$ (maximum $90 \mathrm{~m}$ ), so birds on both sides of the river could be heard. We estimate, based on monitoring singing behavior of Cerulean Warblers, that we sampled riparian corriders ca. $100 \mathrm{~m}$ in width on each side of the river bank (Robbins et al. 2009). Although we recorded the number of detected individuals of 15-19 ripar- 
ian species during all surveys, including repeat surveys of the same routes, because of logistics associated with recording coordinates for literally hundreds of individuals, coordinates were taken for only Cerulean Warbler. Thus, we used this species as a test case to estimate the number of individuals that might be detected during river-based surveys.

To ensure that Cerulean Warbler songs were not confused with Type B (= Song Type II, (Moldenhauer and Regelski 1996) of Parula americana L. (Northern Parula), each Cerulean Warbler was heard singing at least twice before being tallied. GPS coordinates and the side of the river from which the bird sang were recorded for each male; GPS readings were taken at the point when the canoe-based observer was closest to a singing male (i.e., shortest perpendicular distance of male to stream). Because of vegetation density, time, and effort constraints, distances between the canoe-based observer and the eye-level base of the tree from which the bird sang could not be recorded reliably to estimate detection probabilities (Buckland et al. 2001). However, we took distance measurements with a laser range finder from the observer to the singing bird, typically in the crown of emergent sycamores, to obtain approximate distance estimation. All surveys followed BBS weather protocol and were conducted when human volume on the river was either non-existent or very low. A single observer recorded bird detections to eliminate multiple surveyor bias (Sauer et al. 1994).

To estimate the number of Cerulean Warblers not detected on single surveys, repeat surveys were conducted on three river sections: two on the upper Current and one on the lower Buffalo National (details above). All repeat surveys were conducted within two days of the original survey.

In ArcGIS 8.3 (ESRI 1999-2002), we created a 100-m radius buffer around each Cerulean Warbler male GPS location as an approximation to individual territory size. We chose the $100-\mathrm{m}$ radius based on a combination of male territory size and error associated with how GPS readings of male locations were obtained. Average $( \pm$ SD) male Cerulean Warbler territory size was $0.9 \pm 0.1$ ha, with a maximum width by length of $112( \pm 18) \times 87$ $( \pm 33) \mathrm{m}(n=20$ males that were monitored for a minimum of four consecutive hrs, 05:00-09:00; Robbins et al. 2009). GPS readings of singing males were taken from the river (ca. midpoint of the river, river width ranged from ca. 30 to $90 \mathrm{~m}$ ), and buffer location was placed entirely on land from where the bird sang. Although the 100-m radius buffer is larger than our mean territory measurements of densely packed Cerulean Warblers, the position of the male's singing post in relation to the territory as a whole was unknown. When comparing two consecutive (repeat) surveys of the same river section, we treated birds as unique if the 100-m radius buffers representing male territories did not overlap. In those situations where males had contiguous or nearly contiguous territories and not all of these abutting males sang during at least one of the repeat surveys, use of the 100-m buffer may result in underestimates of males present. For example, if during the initial survey, we recorded a male singing at the extremity of his territory where it interfaced 
with an adjacent male's territory, and a repeat survey failed to detect this bird singing, but its adjacent male was singing at the interface of their territories, then our buffer would represent them as a single male. Obviously, if both were singing on either survey or if the males were spaced farther apart, then the buffer would not introduce bias.

We then used resulting numbers of unique and repeated observations of individual Cerulean Warblers to calculate expected total numbers of individuals for each river section by employing the nonparametric estimator developed by Chao (1984) for assessing number of classes in a population when class equality is not assumed. Specifically, from two surveys, it is possible to count individuals twice (both surveys) or once only (one survey or the other); the Chao estimator uses the comparative frequencies of individuals detected twice and individuals detected once to estimate the frequency of individuals likely not to have been detected on either of the surveys. Given that repeat surveys were all conducted within two days of the original count, we treat this as a closed system, i.e., no turnover in males or territory size was assumed to have occurred within that time span. The expected number of individuals $\left(\mathrm{S}_{\mathrm{exp}}\right)$ is estimated as

$$
\mathrm{S}_{\exp }=\mathrm{S}_{\mathrm{obs}}+\left(a^{2} / 2 b\right),
$$

where $\mathrm{S}_{\text {obs }}$ is the total number of individuals observed in either survey, $a$ is the number of individuals observed in only one survey, and $b$ is the number observed in both surveys. A 95\% confidence interval of $\mathrm{S}_{\exp }$ was calculated following Chao (1988).

\section{Results}

We recorded an average of 2.3 and 0.8 singing Cerulean males/river km along $128 \mathrm{~km}$ of the Current River in 2003 (Robbins 2003) and 96 river km of the Buffalo National River in 2006, respectively. The upper and middle stretches of the Buffalo lacked the extensive forested floodplain found in the lower portions, and this was reflected in the number of Cerulean Warblers. An average of 0.3 males/river km were recorded along the middle Buffalo section (64.5 $\mathrm{km})$, whereas the lower section $(31.6 \mathrm{~km})$ had 2.1 males/river $\mathrm{km}$. Ninety-five percent $(n=231)$ of the Cerulean Warblers detected were estimated (see Methods) to be $\leq 100 \mathrm{~m}$ from the canoe-based observer. The Chao estimator allowed estimation of the completeness of our surveys for which we conducted repeat surveys. For example, for the Pulltite section, 22 males were detected during both surveys, while 8 and 5 individuals were detected only during the first or second survey, respectively. As such, for this river section, $a=13, b=22$, and $\mathrm{S}_{\mathrm{obs}}=35$, which leads to an estimate of $\mathrm{S}_{\exp }=38.8 \pm 6.5 \mathrm{SD}$ males expected along this river section (Table 1). Hence, we estimate that a minimum of 8-9 males were missed on the first survey, and 11-12 were missed on the second survey, and that $69-77 \%$ of males were detected on the two surveys. Calculations for males detected on Round Spring were 76-79\% (70.5-79.0, 95\% CI) and $72-74 \%(47.3-56.5,95 \% \mathrm{CI})$ on Maumee. 


\section{Discussion}

The river-based protocol is appropriate for a wide range of water courses that do not have rapid or noisy water flow. For the period 1966-2000, using counts ( $n=8585$ total counts; 50 counts/route) of BBS routes where at least one warbler was recorded, $75.9 \%$ had zero, $12.2 \%$ had one, and $3.3 \%$ had $\geq 5$ individuals (Link and Sauer 2002). These results are indicative of the relatively few Cerulean Warblers that are recorded on BBS routes. In the physiogeographic region of our study (Ozark-Ouachita Plateau BBS region), Cerulean Warblers are a very low-density species along road-based routes in the Missouri and Arkansas Ozarks. During 2003-2007, this species was recorded on only 4 of 43 routes, with an average of 0.12 birds on those four routes (Sauer et al. 2008). In contrast, we documented previously unknown Cerulean Warbler populations that had among the highest densities recorded with an average of $>2.0$ birds/river $\mathrm{km}$ for some Missouri Ozark rivers (Robbins 2003, Robbins et al. 1998) and the lower Buffalo National River in northern Arkansas.

While a canoe-based approach is clearly more effective than road-side surveys in assessing riparian-inhabiting species, how does it compare to other survey techniques that might be employed? In effect, our river-based protocol is a line transect, and as has been underscored by others, linetransect methodology has advantages over point counts (Buckland et al. 2001, Diefenbach et al. 2007). In particular, we consider our river-based, line-transect protocol better suited than riparian-based point counts because of river-associated logistics: i.e., point counts would require additional time associated with canoe pullout and put-in/survey point, and entire sections of rivers can be surveyed increasing the number of observations, and hence accuracy, and avoiding undersampling micro-habitats. An example of a microhabitat that is not randomly distributed along Ozark streams and rivers are stands of Arundinaria gigantea Walter Muhl. (Giant Cane). Ozark

Table 1. Chao's estimator calculations for male Cerulean Warblers on repeat surveys of three river sections of the Current (2003) and Buffalo (2006) rivers.

\begin{tabular}{lccc} 
& \multicolumn{2}{c}{ Upper Current River } & $\begin{array}{c}\text { Lower } \\
\text { Buffalo River } \\
\text { Maumee }\end{array}$ \\
\cline { 2 - 3 } & Pultite & Round Spring & \\
\hline Observed & 8 & 12 & 9 \\
$\quad$ Males counted only on the first day & 5 & 10 & 8 \\
$\quad$ Males counted only on the repeat day & 52 & 46 & 28 \\
Males recorded on both days & 35 & 68 & 45 \\
S $_{\text {obs }}$ & & & \\
Estimated & $38.8 \pm 6.5$ & $73.3 \pm 7.7$ & $50.2 \pm 8.9$ \\
$\quad$ Chao S S & $36.6-44.4$ & $70.5-79.0$ & $47.3-56.5$ \\
95\% CI & 8.8 & 15.3 & 13.2 \\
Males missed on first day & 11.8 & 17.3 & 14.2 \\
Males missed on repeat day & 77.2 & 79.2 & 73.8 \\
\% detected on first day & 69.5 & 76.4 & 71.8 \\
\% detected on repeat day & & & \\
\hline
\end{tabular}


Limnothlypis swainsonii Audubon (Swainson's Warbler) distribution is closely associated with this habitat (Robbins and Easterla 1992). Moreover, this protocol requires minimal effort and costs when compared to labor-intensive protocols such as double-sampling and double-observer. With repeat surveys using the same experienced observer and using the Chao estimator for birds present but missed, one can eliminate among-observer bias and assumptions concerning multiple observer independence associated with double-observer methods (Fletcher and Hutto 2006, Nichols et al. 2000).

During our canoe-based surveys, we often detected continuously singing males at $>100 \mathrm{~m}$ (maximum distance was $250 \mathrm{~m}$ ), before floating by the same male at $<40 \mathrm{~m}$. Based on consistently singing males, our exposure to each male ranged from 3-10 min, with estimated average exposure of $<5$ min. Singing rate and river topology, i.e., whether the stretch was straight vs. highly convoluted, both affected exposure time (see below). Despite efforts in attempting to standardize canoe flow rate, we undoubtedly had varying time exposures to territorial males. Thus, one advantage of land-based point counts over the river-based transect is consistency in sampling period.

Comparison of observed totals/subsection (simple tallies of males encountered, without using any estimators) for all repeated surveys combined indicated that we missed an average of $7.3 \%( \pm 6.9 \mathrm{SD}$; range $=0-18 \%)$ of the male Cerulean Warblers. We underscore that each one of our subsections consisted of several river km; thus, more finely divided subsections, perhaps $1 \mathrm{~km}$ increments, would have revealed that some of the individuals were not the same between the two repeat surveys. The most extreme difference between absolute value of repeat surveys and the 100-m buffer estimate was for one 16-km stretch of the Buffalo River where we recorded the same number of males for each subsection ( $n=3$ subsections with 37 total males) for two consecutive surveys. Based on that absolute count, one might conclude that each male was recorded on both surveys, when, in fact, based on the $100-\mathrm{m}$ buffer estimates, we believe that a minimum of 17 males ( 9 uniques first day, 8 second day) were missed during repeated surveys (Table 1). Based on our repeat river surveys using the $100 \mathrm{~m}$ buffered GPS readings, the Chao estimator suggests that a minimum of between 21 and $31 \%$ of the birds were missed during our river surveys. For repeat BBS counts, the percentage estimates for variability in individuals recorded for the parulid clade $(n=21$ species; Cerulean Warbler was not represented because of small sample size) was $42 \%$ (Link et al. 1994).

Regardless of survey protocol used, it is widely recognized that to obtain better estimates of the number of birds present, detection probabilities must be incorporated through distance sampling (Buckland 2006, Thogmartin et al. 2006), and where aural clues are used, song availability data must be incorporated (Confer et al. 2008, Diefenbach et al. 2007). Although we explored density estimates with the program DISTANCE (Buckland et al. 2001), our river-based protocol did not provide an integral measurement: accurate horizontal, perpendicular distance estimates from 
the canoe-based observer to trees where the canopy-dwelling male Cerulean Warblers sang. Such estimates were impossible given the vegetation structure (i.e., dbh height tree trunks from where birds sang were rarely visible); indeed, an inordinate amount of time and effort would have been needed to clear vegetation for obtaining accurate distance measurements for most individuals regardless of survey methodology. Moreover, we recognize that the fundamental assumption in distance sampling, that $100 \%$ of the survey targets are detected at the point of the count, is consistently violated when aural clues are used in detection. Intensive avian studies using aural cues for detection, ranging from grassland to forest-inhabiting species, have demonstrated that a large proportion of the population is not available (singing) at any given point in time (Confer et al. 2008, Diefenbach et al. 2007, Robbins et al. 2009, Staicer et al. 2006).

When aural clues are used, song availability is integral for obtaining less-biased detection probabilities, i.e., estimating the number of individuals that may be available during any count period (Diefenbach et al. 2007). To obtain an estimate of the number of males that might be detectable based solely on song availability, we monitored, during the same time frame and location (Current River only) that the river surveys were conducted, the singing rates of 24 male Cerulean Warblers for a minimum of four consecutive hours, 05:00-09:00 (Robbins et al. 2009). The mean number ( \pm SD) of 5 -min periods $(n=48)$ over the course of 4 hrs during which male Cerulean Warblers did not sing was $33 \%( \pm 21)$. Thus, availability, i.e., whether males sang during any given period, may explain a large portion of the variability in males detected not only among our repeat river-based counts, but in all survey protocols where vocalizations are used for detection (Confer et al. 2008, Diefenbach et al. 2007, Robbins et al. 2009, Staicer et al. 2006).

Whether one uses the Chao estimator for repeat surveys or only song availability estimates, the average number of Cerulean males within ca. $100 \mathrm{~m}$ of each side of the 128 Current River $\mathrm{km}$ that we surveyed was likely $>3.0$ males/river $\mathrm{km}$ (2.8-3.1 Chao estimator, 3.1 song availability estimate). In order to obtain less-biased detection probabilities to estimate density, a large amount of resources and labor must be invested in obtaining song availability data and distance measurements (the latter would require clearing extensive understory in study areas such as ours) for each species at the time of surveys (Diefenbach et al. 2007). In lieu of those nontrivial investments, we recommend the following river-based protocol for obtaining relative abundance indexes of poorly sampled avian riparian-inhabiting species. Instead of using the laborious method of recording coordinates for each individual during each survey to estimate the number of birds present, we recommend subdividing each river section into $1-\mathrm{km}$ increments and surveying each section twice, preferably on consecutive days to assume that it is a closed system. The Chao estimator can then be used to provide a better estimate of the number of birds present. 


\section{Acknowledgments}

Brad Jacobs and Victoria Grant helped with support and/or logistics. Funding was provided by the Ozark National Scenic Riverways and the Wildlife Division of the Missouri Department of Conservation. Paul McKenzie has provided invaluable help during our Cerulean Warbler work. Alexis Powell, A. Townsend Peterson, and two anonymous reviewers provided comments on the manuscript.

\section{Literature Cited}

Buckland, S.T. 2006. Point-transect surveys for songbirds: Robust methodologies. Auk 123:345-357.

Buckland, S.T., D.R. Anderson, K.P. Burnham, J.L. Laake, D.L. Borchers, and L. Thomas. 2001. Introduction to Distance Sampling: Estimating Abundance of Biological Populations. Oxford University Press, Oxford, UK.

Chao, A. 1984. Nonparametric-estimation of the number of classes in a population. Scandinavian Journal of Statistics 11:265-270.

Chao, A. 1988. Estimating animal abundance with capture-frequency data. Journal of Wildlife Management 52:295-300.

Confer, J.L., R.E. Serrell, M. Hager, and E. Lahr. 2008. Field tests of the RosenbergBlancher method for converting point counts to abundance estimates. Auk 125:932-938.

Diefenbach, D.R., M.R. Marshall, J.A. Mattice, and D.W. Brauning. 2007. Incorporating availability for detection in estimates of bird abundance. Auk 124:96-106.

ESRI. 1999-2002. ArcGIS. Environmental Systems Research Institute, Inc., Redlands,CA.

Fletcher, R.J., and R.L. Hutto. 2006. Estimating detection probabilities of river birds using double surveys. Auk 123:695-707.

Hamel, P.B. 2000a. Cerulean Warbler (Dendroica cerulea). In A. Poole and F. Gill (Eds.). The Birds of North America. The Birds of North America, Inc., Philadelphia, PA.

Hamel, P.B. 2000b. Cerulean Warbler status assessment. US Department of Interior, Fish and Wildlife Service, Minneapolis, MN.

Hamel, P.B., D.K. Dawson, and P.D. Keyser. 2004. How we can learn more about the Cerulean Warbler (Dendroica cerulea). Auk 121:7-14.

Jacobs, B., and J.A. Wilson. 1997. Missouri breeding bird atlas. 1986-1992. Missouri Department of Conservation, Jefferson City, MO.

James, F.C., D.A. Wiedenfeld, and C.E. McCulloch. 1992. Trends in breeding populations of warblers: Declines in the southern highlands and increases in the lowlands. Pp. 43-56, In J.M. Hagan III and D.W. Johnston (Eds.). Ecology and Conservation of Neotropical Migrant Landbirds. Smithsonian Institution Press, Washington, DC. 609 pp.

Link, W.A., and J.R. Sauer. 2002. A hierarchical analysis of population change with application to Cerulean Warblers. Ecology 83:2832-2840.

Link, W.A., R.J. Barker, J.R. Sauer, and S. Droege. 1994. Within-site variability in surveys of wildlife populations. Ecology 75:1097-1108.

Moldenhauer, R.R., and D.J. Regelski. 1996. Northern Parula (Parula americana). In A. Poole and F. Gill (Eds.). The Birds of North America. The Birds of North America, Inc., Philadelphia, PA. 
Nichols, J.D., J.E. Hines, J.R. Sauer, F.W. Fallon, J.E. Fallon, and P.J. Heglund. 2000. A double-observer approach for estimating detection probability and abundance from point counts. Auk 117:393-408.

Panjabi, A.O., E.H. Dunn, P.J. Blancher, W.C. Hunter, B. Altman, J. Bart, C.J. Beardmore, H. Berlanga, G.S. Butcher, S.K. Davis, D.W. Demarest, R. Dettmers, W. Easton, H. Gomez de Silva Garza, E.E. Iñigo-Elias, D.N. Pashley, C.J. Ralph, T.D. Rich, K.V. Rosenberg, C.M. Rustay, J.M. Ruth, J.S. Wendt, and T.C. Will. 2005. The Partners in Flight Handbook on species assessment, version 2005. Partners in Flight Technical Series no. 3. Available online at www.rmbo.org/ pubs/downloads/Handbook2005.pdf. Accessed 20 January 2010.

Peterjohn, B.G. 1994. The North American breeding bird survey. Birding 26:386-398.

Price, J., S. Droege, and A. Price. 1995. The Summer Atlas of North American Birds. Academic Press, New York, NY.

Rich, T.D., C.J. Beardmore, H. Berlanga, P.J. Demarest, E.H. Dunn, W.C. Hunter, E.E. Iñigo-Elias, J. A. Kennedy, A.M. Martell, A.O. Panjabi, D.H. Pashley, K.V. Rosenberg, C.M. Rustay, J.S. Wendt, and T.C. Will. 2004. Partners in Flight North American Landbird Conservation Plan. Cornell Laboratory of Ornithology, Ithaca, NY.

Robbins, C.S., D. Bystrak, and P.H. Geissler. 1986. The breeding survey: Its first fifteen years, 1965-1979. US Department of Interior, Fish and Wildlife Service, Washington, DC.

Robbins, C.S., J.W. Fitzpatrick, and P.B. Hamel. 1992. A warbler in trouble: Dendroica cerulea. Pp. 549-562, In J.M. Hagan and D.W. Johnston (Eds.). Ecology and Conservation of Neotropical Migrant Landbirds. Smithsonian Institution Press, Washington, DC. 609 pp.

Robbins, M.B. 2003. Riparian bird inventory of the Ozark National Scenic Riverways. Summary report to Ozark National Scenic Riverways, National Park Service, Van Buren, MO.

Robbins, M.B., and D.A. Easterla. 1992. Birds of Missouri. Their Distribution and Status. University of Missouri Press, Columbia, MO.

Robbins, M.B., B.R. Barber, and K. Zyskowski. 1998. Census of Cerulean Warblers along the upper Current River, with comments on the status of other riparian species. Bluebird 65:10-16.

Robbins, M.B., A.S. Nyári, M. Papes, B.W. Benz, and B.R. Barber. 2009. Song rates, mating status, and territory size of Cerulean Warblers in Missouri Ozark Riparian Forest. Wilson Journal of Ornithology 121:283-289.

Rosenberg, K.V., and P.J. Blancher. 2005. Setting numerical population objectives for priority landbird species. Pages 57-67, In C.J. Ralph and T.D. Rich (Eds.). Bird Conservation Implementation and Integration in the Americas: Proceedings of the Third International Partners in Flight Conference, Asilomar, California, March 20-24, 2002 Volume 1. USDA, Forest Service, General Technical Report PSW-GTR-191. Pacific Southwest Research Station, Albany, CA.

Sauer, J.R., and S. Droege. 1992. Geographic patterns in population trends of Neotropical migrants in North America. Pp. 26-42, In J.M. Hagan III and D.W. Johnston (Eds). Ecology and Conservation of Neotropical landbirds. Smithsonian Institution Press, Washington, DC. 609 pp.

Sauer, J.R., B.G. Peterjohn, and W.A. Link. 1994. Observer differences in the North American Breeding Bird Survey. Auk 111:50-62. 
Sauer, J.R., J.E. Hines, and J. Fallon. 2008. The North American Breeding Bird Survey: Results and analysis 1966-2007. Vers. 5.15.2008. USGS Patuxent Wildlife Research Center, Laurel, MD.

Staicer, C.A., V. Ingalls, and T.W. Sherry. 2006. Singing behavior varies with breeding status of American Redstarts (Setophaga ruticilla). Wilson Journal of Ornithology 118:439-451.

Thogmartin, W.E., F.P. Howe, F.C. James, D.H. Johnson, E.T. Reed, J.R. Sauer, and F.R. Thompson. 2006. A review of the population estimation approach of the North American landbird conservation plan. Auk 123:892-904. 